\title{
Performance Analysis with Wireless Lan Networks Using the Quality Of Service Method
}

\author{
Anggi Wahyudi, Aulia Fitrul Hadi, RiniSovia \\ Universitas Putra Indonesia YPTK Padang, Indonesia
}

\section{ARTICLE INFORMATION}

Received: January $28^{\text {th }}, 2020$

Revised: March $28^{\text {th }}, 2020$

Available online: April $15^{\text {th }}, 2020$

\section{KEYWORDS}

Network, Wireless, Quality Of Service,

Computer

\section{CORRESPONDENCE}

Phone: +622382759446

E-mail: anggiwahyudi224@gmail.com

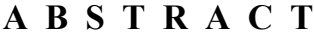

The use of the internet currently has very high mobility, both used for streaming, browsing, downloading and uploading data. Along with the changing times and the demands for information services that are fast, precise, and accurate, making the network a major need, especially in the world of education. The use of internet facilities requires management to manage each data. For this reason, there is a need for Quality of Service on the network to optimize the distribution of networks evenly and fairly for each client and network user. The results of the study show that network quality by implementing Quality of Service is more optimal and network distribution is more even and stable.

\section{INTRODUCTION}

Information technology, especially on computer networks at this time has become one of the basic things in all aspects. It is difficult to imagine in the current era of information technology without using computer network technology. This can be seen from the use of computer networks both publicly and privately, the many needs for access and communication, the network performance must be in good condition, then network operators and internet service providers (ISPs) must be able to solve the main problem of providing service performance which is great for being able to provide convenient services to users. Information and communication technology are essential for everyone. Every day people cannot be separated from information technology. Quality of service is a method of measuring how well a network is installed and also an attempt to define the characteristics and nature of a service [1]. Quality of Service is used to measure a set of performance attributes that have been specified and associated with a service. QoS parameters used for data communication service analysis are jitter, packet loss, throughput, and delay. By using the QoS parameter above, we will know the QoS index value of data communication services. These results will be measured by the internet network and determined the parameter index value. Then the results will be analyzed so they can be optimized.

SMK 1 PADANG including schools that use Wireless LAN networks, where the network is used by various components. From these problems, the performance of the Wirelees LAN network at SMK 1 PADANG must always remain at good performance. Therefore, to know the quality of the Wireless LAN internet network at SMK 1 PADANG network analysis must be performed which emphasizes, how to monitor and measure the performance of Wireless LAN networks and to find out how much network performance on infrastructure such as access speeds from the sending point to the receiving point.

\section{Quality Of Service}

Quality of Service is the ability of a network to provide better services for the traffic services that pass through it. Quality of Service is an end to end architecture system and is not a feature that is owned by the network. Quality of Service of a network refers to the speed and reliability of delivering various types of data load in a communication [2] 

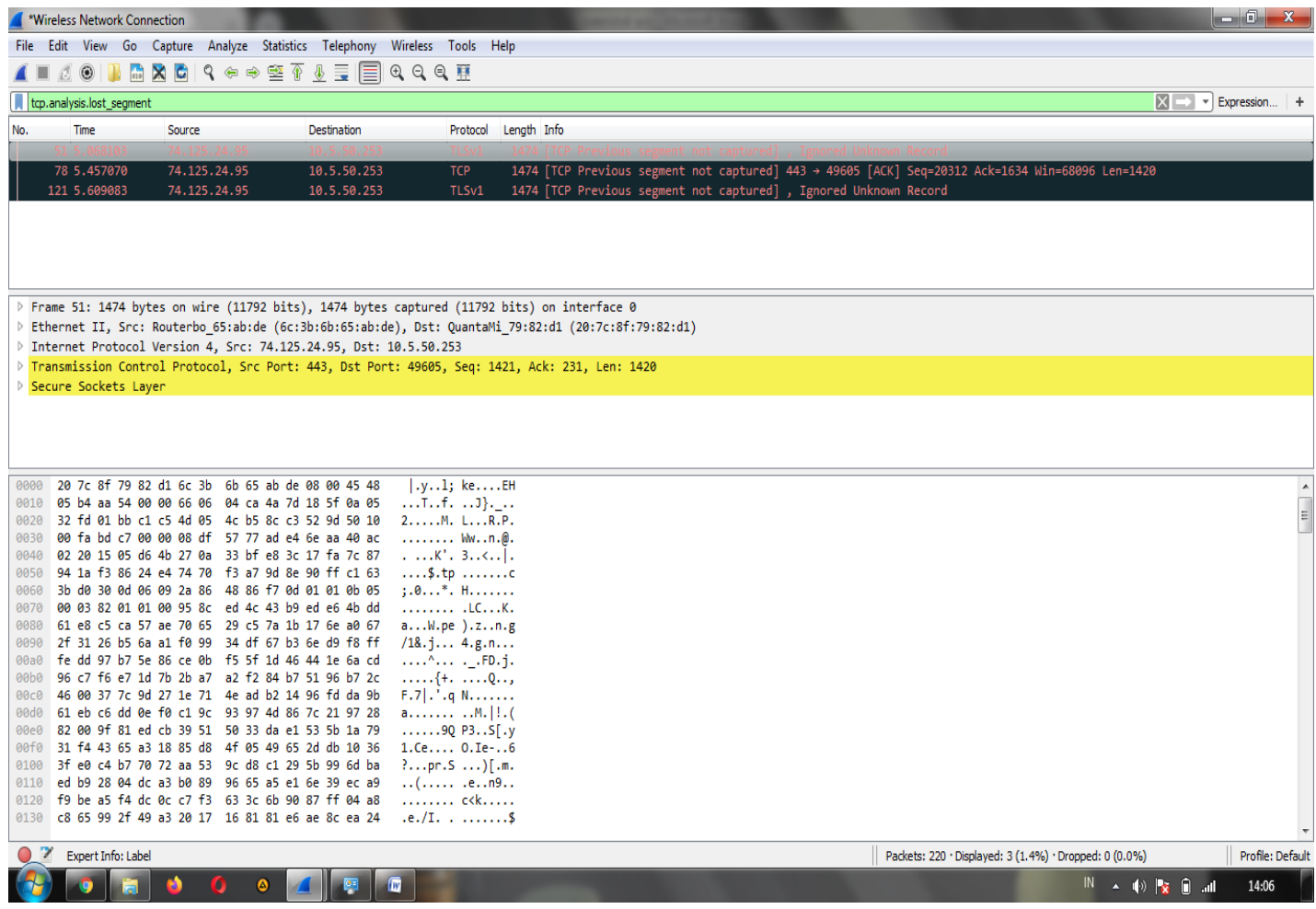

Figure 1. Wireshark is used to record and analyze every packet that passes

\section{Network Topology}

Network topology is the arrangement or mapping of interconnections between nodes, of a network, both physical (real) and logical (virtual) []].

\section{Bus or Linear Topology}

Bus topology is a topology that is widely used during the use of mushrooming coaxial cables. The characteristic of this topology is that one cable has both ends closed where along the cable there are nodes, the most prevevalent because it is simple in installation, the signal passes through a 2-way cable and collisions may occur [4]].

\section{Ring Topology}

Ring topology is a topology in which information and data and traffic are distributed in such a way. Generally, this facility utilizes fiber optic as a means. The characteristics of this topology are closed circles that contain nodes, simple in layout, signals flow in one direction so that collisions avoid [4].

\section{Star Topology}

Star topology is a topology that is widely used in various places, because of the ease to add, reduce, or detect damage to existing tissue [4]. The characteristics of this topology is that each node communicates directly with the central node, traffic data flows from the node to the central node and back again, easily developed because each node only has a cable that is directly connected to the central node, the advantage is that if one node cable is disconnected then the others will not disturbed [4].
4. Tree Topology

Tree topology is a network topology in which this topology is a combination or combination of the three existing topologies, namely the star topology, ring topology, and bus topology [4].

\section{METHOD}

\section{Troughtput}

Throughput is the speed (rate) of effective data transfer, which is measured in bps (bits per second). Throughput is the total number of successful packet arrivals observed at the destination during a certain time interval divided by the duration of the time interval [ $\underline{3}]$.

\section{Packet Loss}

Packet Loss is a parameter that describes a condition that shows the total number of packets lost can occur due to collision and congestion on the network [3].

\section{Delay}

Delay (Latency) is the time taken for data to travel from the origin to the destination. Delay can be affected by distance, physical media, congestion or also a long processing time [3] . 


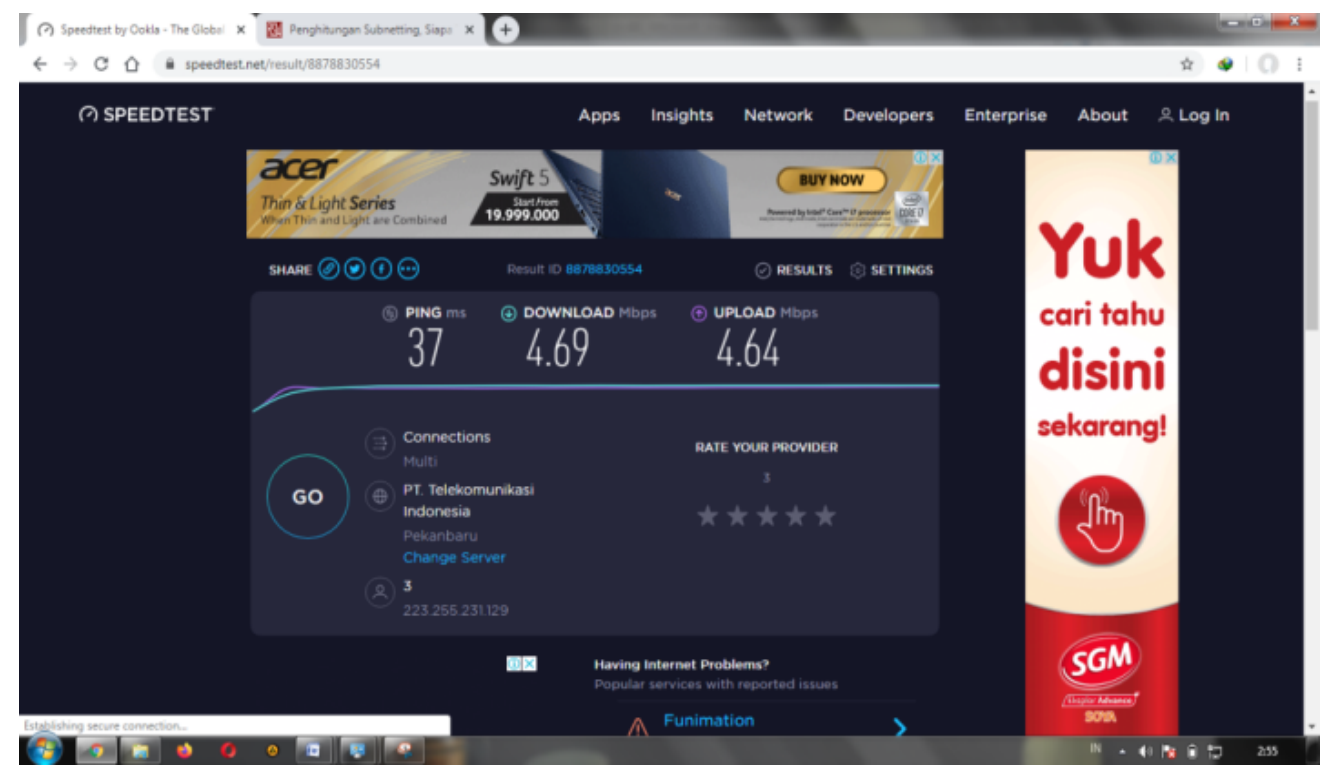

Figure 2. measure network speed ie index ping, download, upload

\section{Jitter}

Jitter is caused by variations in queue length, in data processing time, and also in the time of recompiling packets at the end of a jitter trip. Jitter, commonly called delay variation, is closely related to latency, which shows the amount of delay variation in data transmission on the network [3] .

\section{RESULTS AND DISCUSSION}

To give an overview of the work system that runs currently on the old computer network system that exists at SMK 1 PADANG using a wireless router with a series of tree topologies with a total bandwidth of $100 \mathrm{mb}$, where all computers are connected with users using a wireless router. All computers can be connected to the internet, but due to the limited available bandwidth, on certain days and at peak operational hours there is often a connection disruption.

\section{Wireshark}

Wireshark is a network analyzer program that is very popular at the moment, but strangely this program is mostly known not because of its main function but because it is often used for beginner hacking purposes. Because of this deflection of functions, MeretasDC found it very interesting to discuss the functions and understanding of Wireshark and how to use wireshark
Actually Wireshark is not designed for hackers. Its main function is not intended for hacking. Wireshark is primarily made for Network Administrators to be able to track what is happening in their network or to make sure the network is working well, and no one is doing bad things on that network

How does Wireshark work? Broadly speaking, the work of Wireshark consists of two stages. Record all packets that pass through the selected interface (Interface is a connecting device between networks, can be via wifi or ethernet / lan card). The results of the recording can be analyzed. here we can filter the protocol what we want such as TCP, http, UDP and so on. Wireshark can also record cookies, posts and requests.

Table 1. Testing Parameters Before Optimization

\begin{tabular}{lcccc} 
Pengujian & Throughput & $\begin{array}{c}\text { Packet } \\
\text { Loss }\end{array}$ & Delay & Jitter \\
\hline LAN Labor & 135,23 & $0 \%$ & $226 \mathrm{~ms}$ & $\begin{array}{c}14.9 \\
\mathrm{~ms}\end{array}$ \\
\hline $\begin{array}{l}\text { LAN Tata } \\
\text { Usaha }\end{array}$ & 23,98 & $0 \%$ & $\begin{array}{c}190.6 \\
\mathrm{~ms}\end{array}$ & $\begin{array}{c}9.94 \\
\mathrm{~ms}\end{array}$ \\
\hline WIFI & 396.26 & $3 \%$ & $\begin{array}{c}390.6 \\
\mathrm{~ms}\end{array}$ & $\begin{array}{c}15.19 \\
\mathrm{~ms}\end{array}$ \\
\hline
\end{tabular}




\section{Speed Test}

Speedtest is a service to test the speed and performance of internet connections, both cellular and Wi-FI, developed by Ookla. This service was first launched in 2006 and to date the Speedtest service has been used more than 25 billion times to test internet speed.

Speedtest service is available in the browser via the Speedtest.net site. Not only that, the Speedtest application can also be downloaded on various platforms including iOS, Android, macOS, Windows, and Apple TV.

If it is your first time using Speedtest you will be faced with terms such as ping, download speed and upload speed. The following are the meanings of each of these terms:

- Ping is your connection reaction time, simply how quickly you get a response after sending a request. Ping is measured in milliseconds (milliseconds). Generally, the lower the ping value, the more quality your internet connection will be.

- Download speed shows how fast you can pull data from the server to your device. Download speed is measured in megabits per second (Mbps).

- Upload speed shows how fast the connection is to send data from your device to others. This indicator is also measured in units of megabits per second Mbps).

Table 2. Network Speed Testing Before Optimization

\begin{tabular}{cccc}
\hline Index & Labor & Tata Usaha & WIFI \\
\hline Ping & $83 \mathrm{~ms}$ & $74 \mathrm{~ms}$ & $86 \mathrm{~ms}$ \\
\hline Download & $0.50 \mathrm{mb}$ & $4.69 \mathrm{mb}$ & $0.96 \mathrm{mb}$ \\
\hline Upload & $0.46 \mathrm{mb}$ & $4.64 \mathrm{mb}$ & $0.90 \mathrm{mb}$ \\
\hline
\end{tabular}

Throughput and Packet Loss calculations using formulas Throughput $=$ amount of data sent $/$ delivery time. so that it produces calculations with the results like the table below

Table 3. Testing Parameters After Optimization

Testing Throughput $\begin{gathered}\text { Packet Doss Jitter } \\ \text { Loss }\end{gathered}$

\begin{tabular}{lcccc}
\hline LAN Labor & 1,58 & $0 \%$ & $\begin{array}{c}232.8 \\
\mathrm{~ms}\end{array}$ & $\begin{array}{c}394 \\
\mathrm{~ms}\end{array}$ \\
\hline $\begin{array}{l}\text { LANTata } \\
\text { Usaha }\end{array}$ & 1,47 & $0 \%$ & $\begin{array}{c}221.4 \\
\mathrm{~ms}\end{array}$ & $\begin{array}{c}14.30 \\
\mathrm{~ms}\end{array}$ \\
\hline WIFI & 3.67 & $1.5 \%$ & $\begin{array}{c}523.6 \\
\mathrm{~ms}\end{array}$ & $\begin{array}{c}26.60 \\
\mathrm{~ms}\end{array}$ \\
\hline
\end{tabular}

Table 4. Network Speed Testing After Optimization

\begin{tabular}{cccc}
\hline Index & Labor & Tata Usaha & WIFI \\
\hline Ping & $48 \mathrm{~ms}$ & $37 \mathrm{~ms}$ & $72 \mathrm{~ms}$ \\
\hline Download & $11.67 \mathrm{mb}$ & $12.80 \mathrm{mb}$ & $16.52 \mathrm{mb}$ \\
\hline Upload & $5.14 \mathrm{mb}$ & $14.97 \mathrm{mb}$ & $12.54 \mathrm{mb}$ \\
\hline
\end{tabular}

48 Anggi Wahyudi

\section{CONCLUSIONS}

By implementing Quality of Service shows better and more even bandwidth usage for each network user in SMK 1 PADANG calculated on the QoS Router option enabled. IP address management and network topology have an impact on better network usage and eliminating IP in every unit in SMK 1 PADANG. Analysis by Fixing Services that can cut packages that failed to send. The results of testing the Service Quality parameters describe a more stable network by optimizing the capacity that can be worked out by the router maximally.

Network topology must use high requirements to support a good network.

\section{REFERENCES}

[1] Triuli Novianti And Anang Widiantoro (2016). ANALISA QOS PADA IMPLEMENTASI IPV4 DANIPV6 DENGAN TEKNIK TUNNELING.

[2] Hasanul Fahmi (2018). ANALISIS QOS PENGUKURAN DELAY, JITTER, PACKET LOST DAN THROUGHPUT UNTUK MENDAPATKAN KUALITAS KERJA RADIO STREAMING YANG BAIK.

[3] Banbang Sugiantoro And Yuda Bani Mahardikha (2017). ANALISIS QUALITY OF SERVICE JARINGAN WIRELESS SUKANET WifiDI FAKULTAS SAINS DAN TEKNOLOGI UIN SUNAN KALIJAGA.

[4] Rika Wulandari (2016). ANALISIS Qos (QUALITY OF SERVICE) PADA JARINGAN INTERNET (STUDY KASUS : UPT LOKA UJI TEKNIK PENAMBANGAN JAMPANG KULON-LIPI). 